\title{
Child's Playing Perception in Settlement Public Space in Yogyakarta
}

\author{
Rini Darmawati ${ }^{1}$, Hastuti Saptorini ${ }^{2}$ \\ ${ }^{1}$ Department of Architecture, Islamic University of Indonesia, Yogyakarta \\ 2 Department of Architecture, Islamic University of Indonesia, Yogyakarta
}

\author{
Article History \\ Received : 11 July 2018 \\ Accepted : 11 July 2018 \\ Published : 01 October 2018
}

\begin{abstract}
Preference discrepancy of playground between user (Children) and planners still found in several housing and settlement in Yogyakarta. This happens because of the Choice Model which means that each person and group has a choice of different models especially for children. This paper is an embodiment of the research of the author with the title "Children's Perception of the Playroom with a Review of Comfort and Security. Case Study in Blimbingsari, Cokrodiningratan and Kotagede Hamlets in Yogyakarta City". Through the graphic / drawing method, children convey their perceptions to express the desire to play in the public space. Equipped with some pictures documentation of children's behavior playing, the author studied it uses persepsional analysis to find models of children's desires for the playroom. The results of the study found that there are 5 elements that express children's expectations in play, namely communal community, play settings that are full of natural elements, there are tools / media as play media, public amenities as a magnetude gathering of children, and the last element is that children are conducive and safe playing when there is free time and air is comfortable, namely during holidays and afternoons.
\end{abstract}

Keywords: Children's perceptions, children's pictures, playing elements

\section{Introduction}

The world of children who have never been separated from their lives is playing. This activity is a builder of children's character both in terms of cognition, affection, and psychomotor. Unfortunately, not every place of residence / settlement, provide a conducive playroom according to their needs and desires.

Spontaneously, the play area is created in a certain space around their residence. "Place" in any form is often built as a playground. It is means that with minimal physical and non physical conditions, children play spontaneously. When playing, the children is seen as having chosen the right location and open space. This is emphasized by Rapoport in Suprayoga et al (2007) which states that children have attention to various

Correspondence: Rini Darmawati

Department of Architecture, Islamic University of Indonesia, Yogyakarta

E-mail: rini.darmawati@uii.ac.id subjective attributes regarding the quality of their environment. But often the neighborhood planning and children's play facilities are based on the preferences of planners and designers, so that what appears to be called a gap in preferences by users.

This is called the choice model which means that each person and group has a choice of different models.

Marcus (1998) illustrates that children have unique ways to respond to their physical environment. They don't care about the condition of the playroom. The area of space is narrow, and complicated to access, for them it is not a challenge to play together with other friends. A number of experiences in several dense settlements indicate that 5 children play rubber or yeye in the aisles / circulation between buildings. Although there are jumping movements and need wider space, they can adapt to the condition of the remaining space as a playroom. Other experiences show that there were three children riding on the roof of 
the house to release pigeons. The condition of the playground has no boundaries, so it can be said to be unsafe. Even so, children still enjoy playing in that place.

The gap between these conditions and the ideal standard of the playing room is an urgent per-suasive problem to study. Children's perceptions in playing are one of the criteria used as a consideration of the quality of the design of the playroom in public buildings in general, and housing specifically.

Halim (2005) defines perception as a process for someone to obtain information about the environment. The method of knowing children's perceptions is through images media, with the consideration that drawing is an individual expression that can be used as a communication tool (Karczmarzyk, 2012). Furthermore Karczmarzyk explained that through images, children can tell more things to readers than to language. Children do not have sufficient ability to express abstract linguistics, but have a method of symbolic communication by drawing. Children's pictures of the playroom will be interpreted. This meaning relates to perceptions that show the desire of children with values implied in the playroom.

Relevant studies have been carried out by a number of researchers. Loita (2017) found in his research that every child's play is often the environment used as an object of drawing work. Usually each picture has a special meaning or story for the child. Because they draw while fantasizing and imagining, so playing activities are physical and spiritual activities that are important to be considered by educators / adults (p.12). Setiawan (2006) found that children's perceptions of the river and its environment as a playful and challenging place to play. Taking objects in the North Code village, Yogyakarta the researchers found the perception of the child with in-depth interview methods and picture media. Images made by child are mental maps of the use of space around the river.

Patilima (2004) found in cognitive research on children in Indonesia, especially children in Kwitang Village, Central Jakarta, regarding perceptions of the city environment. The perceptual description which found is the understanding and experience of the child towards the environment of residence, community environment, school environment, playing environment, training in transportation and health services. Perception of the availability of environmental facilities (kampling posts, etc.) and the panic of street furniture (lights, roads and so on) are perceived by children as a comfortable and safe atmosphere for activities (including playing) in their neighborhoods.

Similar findings were written by Clark (2004) in Dudek (2005) through his research regarding values towards a space. The children were invited to visit the nursery, then they were asked to express the feeling of the space they liked and did not like, through in-depth interviews. An interesting place for children is a space that accommodates them to meet each other and there is something that can be used as a sign. Seated benches are seen as a landscape element that is very attractive to children. Children assume that the play center is a park that can be used to gather and create "findings". The study illustrates that the parameters mentioned as findings are a "feeling / emotion / desire / value" for children in play. That is, the child ex-pects "certain criteria" in the play area to be used as a design basis by the "Planner and Designer". Therefore, the gap in preferences by users of the playroom can be minimized.

This paper aims to examine the perceptions of children in playing in the Public Space of populous Settlements. The contents of the study are the results of research conducted in 2017 entitled: "Children's Perceptions of the Playroom with a Review of Comfort and Security, a case study of 3 Hamlets in Yogyakarta: Blimbingsari, Cokrodiningratan and Kotagede.

\section{Literature Review and Theoretical Basis}

Playing is a child's activity carried out for pleasure without knowing the end result (Hurlock, 1995a). This activity is carried out voluntarily and without coercion. Running around, circling, going up and down stairs, cycling, cycling or playing swing is a play activity that is a voluntary activity, and happily without coercion.

Dudek (2005) underlines that play activities have a very large influence on children's mental 
development. Because, he said, that the play will build up the soul of the child from an intellectual, physical, and emotional side. Playing is a powerful medium for expressing yourself, social learning, imagination, the introduction of the world and physical skills. In the early period, children are periods of extraordinary fantasies (Said, 2007). Furthermore, Said (2007) explained that elementary school age children are the childhood period of exploring and relating to nature.

Hurlock (1995a) also emphasized that playing activities had a positive influence on children's development, in terms of the following 7 points:

1. Physical development of children is useful for developing muscles and training all parts of their body.

2. Children's knowledge

Playing provides an opportunity for children to explore the environment that is not obtained by children from studying at home or school.

3. The development of children's creativity through experimentation in play, children find that designing something new and different can lead to satisfaction.

4. Children's social behavior

Children play with other children, are learning activities to form social relationships and solve problems that arise in the relationship.

5. Children's moral value

Children can develop honesty and respect for other friends.

6. Distribution for hidden emotional energy.

7. Playing is a forms of channeling tension caused by environmental restrictions on their behavior.

\section{Child And Place Environment They Live In}

Piaget in Mimica (1992) explains the ability of children to respond to the environment, understand in three glass, namely as follows.

The First stage: Pre operational

This stage is experienced by children aged 5 years to 9 years, who are aware of the form of relationships:

a. Proximity, b. Separation, c. Order (order), d.Surounding (around), e. Continuity.

The second stage: Concrete Operational stage.
This stage is experienced by children aged 9 years to 13 years old. This age child can already choose alternatives, combinations and extension of routes, changes in the order / sequence of routes and clear directions.

The last stage: Formal Operational

The final stage is achieved when the child is 13 years old. This stage, the child understands spatial relationships in abstract.

Ancok (2006) wrote in his book Behavioral Sciences in Human Resource Development that mental training conducted in the open (natural) will build emotional excitement and excitement. He added, learning in a happy mood will greatly help the effectiveness of the learning process (Ancok, 2006). This is also indicated by Gifford (1987) on the learning process in incidental settings, namely playground, park, family room, and office. This non-formal learning process often occurs spontaneously, which in the process is influenced by two variables, namely personal characteristics and environmental characteristics. In this study the characteristics of children differ according to their experience, background and culture. Environmental characteristics also differ according to their place of residence, frequently visited places and dreams of places to visit. For example the characteristics of the environment in dense residential areas, the location of adjacent houses, narrow and dark alleys, limited open areas, sometimes muddy because the road is uneven and less clean.

Research on children's perceptions of the river and its environment was carried out by Setiawan (2006). The location of the research on children's perceptions was carried out in the North Code village, Yogyakarta. Methods of looking for data not only by in-depth interviews but also with media images. Child-made images are mental maps of the use of space around the river. The conclusions from this study include, perceptions about the area around the river are very positive. Children use the river area for challenging and fun playgrounds. Natural elements known by children around the river, namely water, fish, trees, clouds, rocks and ducks become stimulants for imagination.

\section{Perception}

Haryadi (1995) describes the environmental perception, namely the interpretation of a 
setting by an individual, based on the cultural background, reasoning, and experience of the individual. This terminology is reinforced by Halim (2005) which explains that perception helps individuals to describe and explain what is done by individuals. Each individual has a different perception of the environment, because of different cultural backgrounds, reasoning and experiences. Thus some groups of individuals have a tendency to have a perception of the environment because there are similarities in cultural background, reason and experience. Perception requires a real meeting with an object and also requires a process of cognition and affection.

Perceptions of two individuals have differences because there are differences in past experience and what is desired even with the same stimulus (Porteous, 1977). Meiss (1990) states that someone provides information on architectural experience using tools of vision, hearing, smell, taste and body movement. Children can respond to their environment quickly and in detail. They feel high, near, rough-soft, light-dark. Physical environment makes a stimulant for the exploration of his imagination (Marcus, 1998). The senses are very sensitive to stimulants, namely capturing: colors, surfaces, shapes of objects, climate, trees, animals, layout of activities, so that children interact and learn with the environment. White (1988) states that children have unique ways of responding to nature. Chikdren Closeness to the natural environment is closely related to the development of children. Perceived environment is a product or form of the perception of the environment of a person or group of people. Environmental perception includes the processes of cognition, affection, and cognation of a person or group of people facing the environment. The process of cognition includes the process of perceiving, understanding, and thinking about an environment. The affection process includes the process of feeling (feeling) and emotions (emotion), desires (desires), and values (values) about the environment (Haryadi, 1995).

Feeling that is feeling or inner state when facing (feeling) something (online Indonesian dictionary). Emotions are interpreted as a burst of feelings that develop and recede in a short time. Ambition is interpreted as desire, will hope and values (Indonesian dictionary). The wishes of children gather in several places, generally because they want to meet other people to interact socially and discuss.

Values are a deep feeling that is owned by someone who will determine the behavior or behavior of a person. An explanation of feeling related to values towards a space can be exemplified in Clark's research on children visiting nurseries (2005). Children are asked to express feelings of space that are liked and disliked. There is a diversity of places that children feel as an attractive place, namely on wooden bridges over sand areas, arched benches, fruit spaces, namely places of social interaction and discussions with adults. The values that are implied in addition to being attractive places, also as a place of interaction and discussion that provides comfort to children. Non-verbal communication related to the environment includes three things, namely fixed-feature elements, semi-fixed elements and non-feature elements. Fixed-feature elements are permanent elements such as walls, ceilings and floors. In this study fixedfeature elements on the playground for example toy swings. Semi-fixed elements are easy to move elements such as plant pots, curtains and so on. Non-feature elements relate to the user of a space, such as body position, facial expressions and others.

\section{Children, Perception and Image}

Drawing is a kind of individual expression, which is a communicative tool (Anna, 2012). Oguz (2010) also strengthens that drawing is an important element of children's lives. Furthermore Anna (2012) describes that drawing can tell more things to readers than words. Children do not have sufficient ability to express abstract linguistics, but have a method of symbolic communication by drawing. Children can draw various types of images according to their level of development and by using their creativity. Pictures of children can show their own lives, namely close friends, family, home environment and social environment (Oguz, 2010). Children's images have a sequence of developments, namely the development of motor skills, emotional development, psychosocial development and perceptual development. Children draw "what they know" in their own style. The functions of perception, sensibility / emotions and motoric functions interact, and 
factors of social experience as outlined in the picture (Karczmarzyk, 2012). What the child thinks is translated into the picture is to draw communication. Karczmarzyk (2012) in his writing that discusses the meaning and image of children giving keywords: picture-messages, picture-text, which means that the image is a product of children's thinking. In a study in Florence, images of children from grade 1 to grade 5 found interesting tendencies (Farokhi and Hashemi, 2011). "Home" is depicted in $60 \%$ free images made by children aged 6 and 7 years. In this picture, only a few objects are described besides "home" (such as trees and flowers). "Home" reflects the "emotions and stability" that exists in life in the home, the place where basic needs are obtained, and the place where most childhood lives are.

\section{Settlement Public Space}

Public spaces are open or closed spaces that can be accessed by the general community, including children. Mastuti F. et al (2016) defines public space as public space or land, where the public can carry out functional public activities and other side activities that can bind a community, either through daily activities or regular activities. The settlements intended here are original settlements in 3 hamlets in Blimbingsari, Cokro-diningratan, and Kotagede.

\section{METHOD}

The method of discussing this paper is a breakdown of the data and findings obtained from the research mentioned, the author's article, and other relevant references. In paragraph, the study method in question is as follows (Figure 1).

Figure 1. Study Method

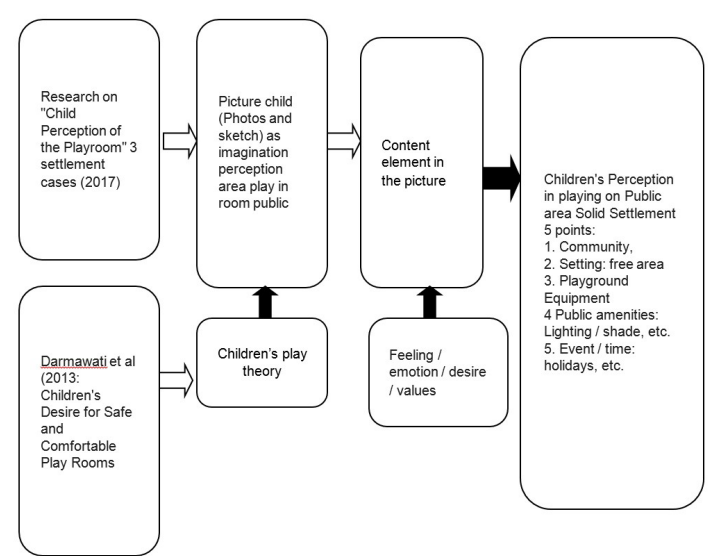

The subjects studied were children aged 5-9 years (Kindegarten, elementary school grades 1 to 4) who lived in Blimbingsari, Cokrodiningratan and Kotagede with consideration of children of this age is the pre-operational stage (Piaget in Mimica, 1992). This age child is aware of the forms of relationships: a. Proximity, b. Separation, c. Order ,d. Surrounding, e. Contiunity (sustainability). Criteria for selecting children as subjects, namely in addition to age range, ease of being found and willingness to be the subject of research by drawing on $A 3$ paper. The number of subjects in Blimbingsari were 3 children who lived in one RT namely RT 1, eleven children in Cokrodiningratan were residents of various RT. The subjects from Kotagede are 8 students from SD Kleco Kotagede. Each subject made a picture of the playroom that they liked, except for 3 children from Blimbingsari who also made pictures of the playroom that they did not like. From 25 images that was produced, there were only 13 that matched the criteria for the research objectives.

\section{Operational Definition}

\section{Children}

Children are respondents who live in 3 villages that were used as research locations. They are children aged 5-9 years.

\section{Perception}

Perception (Robbins, 2003) is the process taken by each individual to organize and interpret the impressions of the senses that you have in order to give meaning to the surrounding environment. Perceptions in this study are feelings, (emotion) / desires, and values about the environment of the child as outlined in the form of images.

Play

Playing is a child's activity carried out in filling his spare time.

\section{Public Space}

Public spaces are open or closed spaces that can be accessed by the public community including children.

\section{Picture}

The picture referred to here is a visual product in the form of sketches and / or photos that express the picture of the playroom. 


\section{Analysis / Discussion Method}

The analysis / discussion was carried out by linking descriptively the parameters of perception and elements of play as outlined in the picture. Images of children's work as research subjects are examined and read the existing signs (Karczmarzyk, 2012). The signs in question are the elements contained in the picture of the child's playroom. The parameters in the picture include settings, play tools and environmental completeness (Public Amenities). Two parameters consist of community and time implied in the supporting photo. Table 1 is the correlated parameter to find strong parameters that children imagine when playing in residential public spaces.

Table 1. Relationship of perception parameters and elements in the image as an analysis method.

\begin{tabular}{|c|c|c|}
\hline Data & Method & Output \\
\hline $\begin{array}{l}\text { The Conditions of } \\
\text { Klewer Market }\end{array}$ & $\begin{array}{l}\text { Descrip- } \\
\text { tive Qual- } \\
\text { itative }\end{array}$ & $\begin{array}{l}\text { Description of the Klewer } \\
\text { Market conditions after } \\
\text { revitalization }\end{array}$ \\
\hline $\begin{array}{l}\text { The Facilities and } \\
\text { Utilities }\end{array}$ & $\begin{array}{l}\text { Descrip- } \\
\text { tive Qual- } \\
\text { itative }\end{array}$ & $\begin{array}{l}\text { Identify the facilities and } \\
\text { utilities of Klewer Market }\end{array}$ \\
\hline $\begin{array}{l}\text { Management of } \\
\text { Klewer Market }\end{array}$ & $\begin{array}{l}\text { Descrip- } \\
\text { tive Qual- } \\
\text { itative }\end{array}$ & $\begin{array}{lr}\text { Identify } & \text { management } \\
\text { of Klewer } & \text { Market in } \\
\text { supporting } & \text { trading } \\
\text { activities } & \end{array}$ \\
\hline
\end{tabular}

\section{Data and Discussion}

Children's perceptions of the playroom are manifested through the elements contained in the image media, both child-made sketches, and photos collected during the study. Referring to Karczmarzyk (2012), the image of the child is a manifestation of "what is known" and "what is envisioned". The manifestation contains the content of emotions / desires /values that are examined through the elements of play contained in picture.

\section{Community}

Community is the child's play element that most often appears in each illustration of their image. The community shown illustrates that children play when they are followed and accompanied / communal with friends (Figures 2 and 3 ). In this case, gender is not a problem in the community (Figure 3 ). A sense of togetherness and an atmosphere that is "tense / crowded" is a delusion of children who are considered to be exciting and inspiring ideas. This is in line with the findings of Latifah et al (2015) who perceive that playing communal scale builds social strength from the side of competition, togetherness, and mutual need. . Besides, that the relationship of kinship is a bond and memories that are built through playing communally, although for them these parameters have not been intentional as a goal.

Figure 2. Children play together riding a bicycle near the house.

source: Author's Document, August 2017

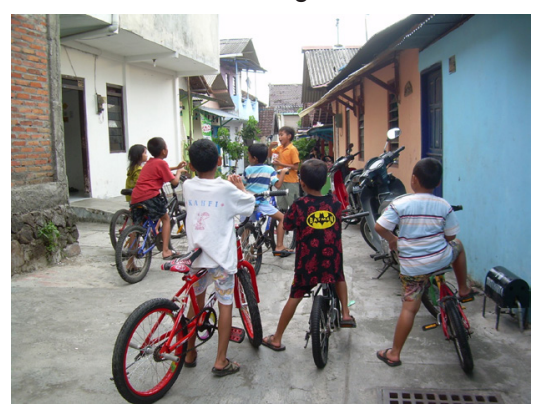

Figure 2a. Sketch of children in Kotagede source: Author's Document, August 2017

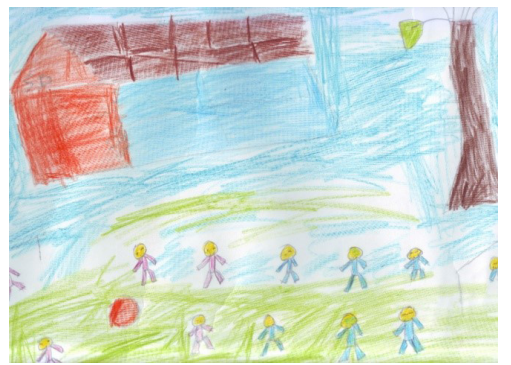

Children who play on an individual scale can also occur in public spaces. This symptom builds up when equipped with sufficient settings and tools. Figure 4 illustrates that children can also play individually by scratching "steples as drawing tools" on the ground / sand. In this case, the play that is built is a form of cognition. Children's thoughts / ideas are poured in "pictures" that are scratched on the sand.

Figure 3. Boys and girls play together source: Author's Document, August 2017

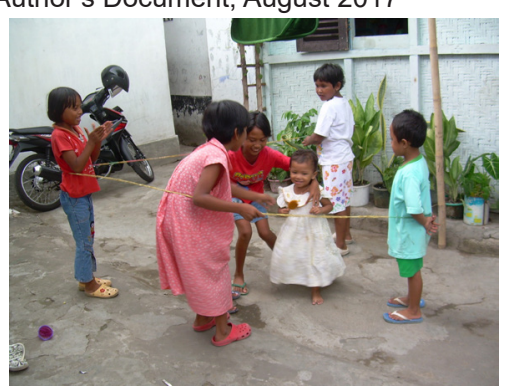


Figure 4. Illustrates that children can also play individually source: Author's Document, August 2017

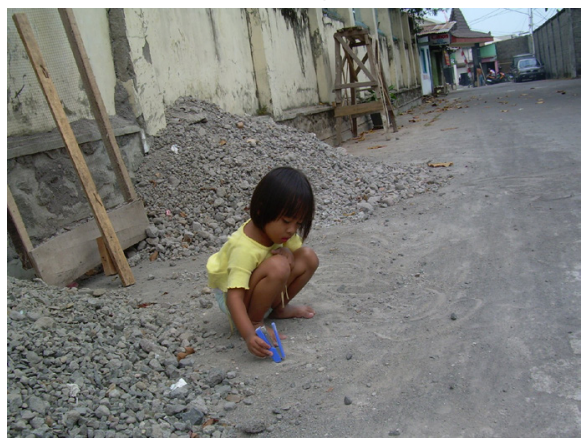

\section{Play Settings}

Play settings are envisioned as a place with a cool natural environment so it is comfortable to play. Figures 5 and 6 are the settings that are envisioned by them, namely setting the edge of the village with a beautiful view that can see the mountains, the banks of the river that have fish. The place can be for playing, walking and jogging. This shows that the setting that depicts a mountain or paddy is thought by children as a place to play because it has fresh air. This is as described by Vastu-shilpa (1988), that thermal comfort provides certain effects and experiences / sensations. Judging from the visual comfort, children want to see beautiful scenery, and psychologically can provide a cheerful atmosphere. The senses are very sensitive to stimulants, namely capturing: colors, surfaces, shapes of objects, climate, trees, animals, layout of activities, so that children interact and learn with that environment (Marcus, 1998). The physical environment, in this case makes a stimulant for the exploration of his imagination. The research conducted by Setiawan (2006) in Blimbingsari on children's playrooms in urban villages located on the banks of the Code River, through the meaning of children's images and interviews, concluded that to develop children's cognition, children are expected to interact directly with existing natural elements. Said (2007) also stated that childhood is a period of extraordinary fantasy, the time of exploring and linking with nature.

\section{Play tools}

The play tool is the third element that evokes play activity. This dream is interpreted from the sketch they describe (Figures 7, 8, 9). Balls, bicycles, stilts, kites and so on. is a play tool that often appears in their sketches. That is, playing tools are elements that are needed as
Figure 5. Beatiful place, shady and clean source: Sketch from elementary 4th class in Blimbingsari, author's document, August 2017

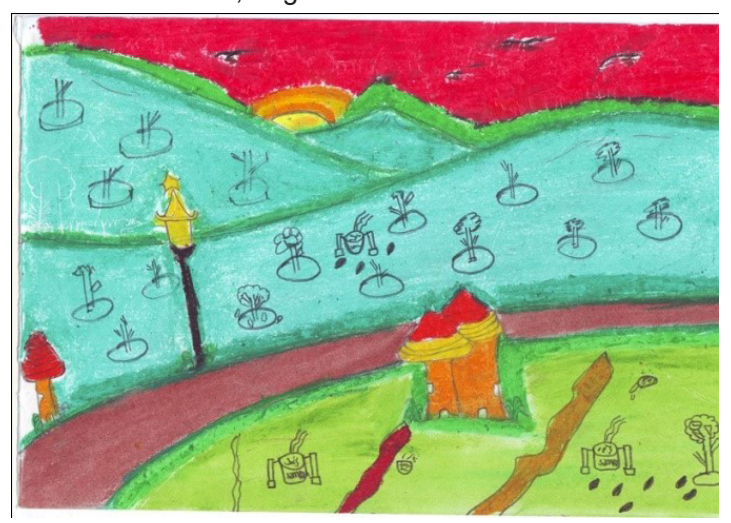

Figure 6. Beautiful place in mountain

source: Sketch from elementary 4th class in Blimbingsari, author's document, August 2017

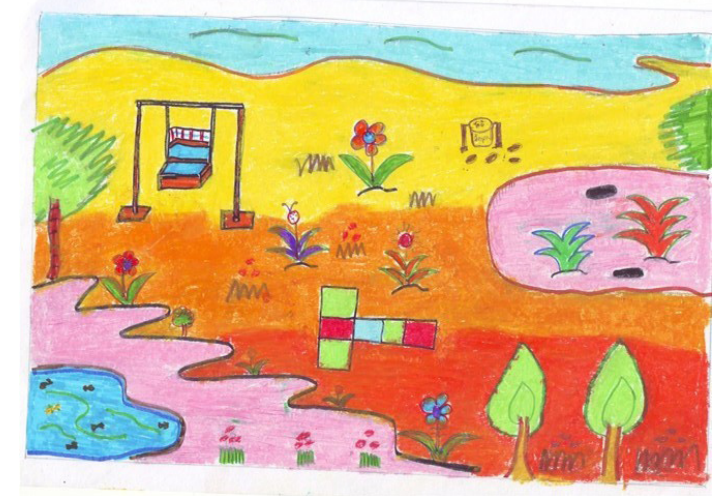

a media to play.Besides that, the landscape elements around the residential environment are also a part that he uses for playing media. Leaves, flowers, sand, water, do not escape use as a medium to play. In principle, the play tool that this child envisions is useful for the devel-opment of cognition, affection and psycho-motorics.

Play tools that use these natural elements, are children's play media that are used to form a certain imagination. Hijriati (2017) emphasizes that play tools that have the nature of forming, compiling, assembling, etc., stimulate the development of children in a positive way. In this case the illustration that the child embodies is the result of a thought process that strengthens intelligence.

Other props that are described as means of movement such as stilts, bicycles, balls, and so on. is a child's imagination that stimulates psychomotor and affection. 
Child's Playing Perception in Settlement Public Space in

Yogyakarta

Rini Darmawati, Hastuti Saptorin
Figure 7. Plastic balls are an element simple tool that invites children to play.

source: author's document, August 2017

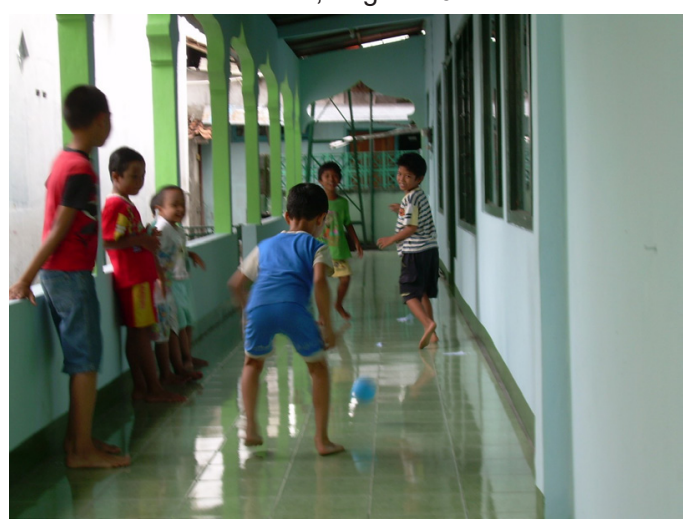

Figure 8. The picture of a swing under a shady tree is an element of a tool / device that invites children to play. source: author's document, August 2017

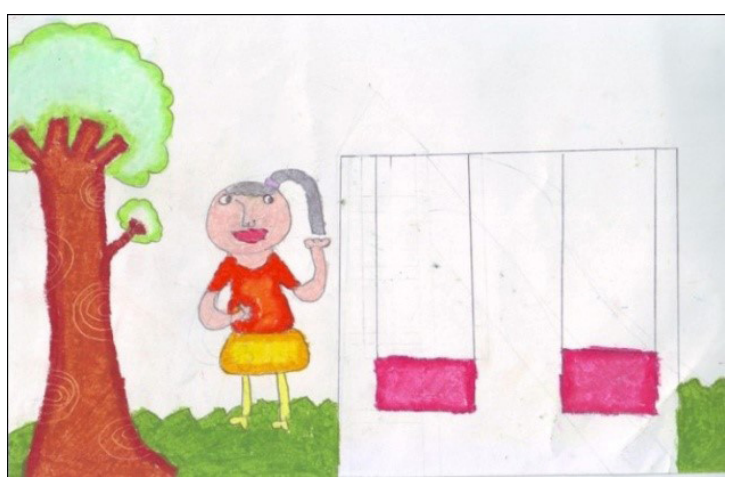

\section{Completeness (Public Amenities)}

Environmental Completeness (Public Amenities) is a "public facility" that can be used as "magnet" to invite children to play. The functions of perception, sensibility / transition and motor function, and social experience factors as out-lined in the picture (Marcus, 1998) explain the senses of children that are very sensitive to stimulants, which are captured: colors, surfaces, shapes of objects, ecosystems, trees, animals, layout of activities, so that children can learn and learn with that environment.

\section{Playing Time}

Playing time is an "intangible" element for the realization of children's play activities. This element is not revealed explicitly in their imagina-tion in the picture. But empirically, the facts show that when the activity is carried out is a time dimension that proves the continuity of the child's playing. In the weekly cycle, holidays are a safe opportunity and fun to play communally.
Figure 9. Stools and courtyards that are relatively free, free to gather are used as a complete environment that invites children to play.

source: author's document, August 2017

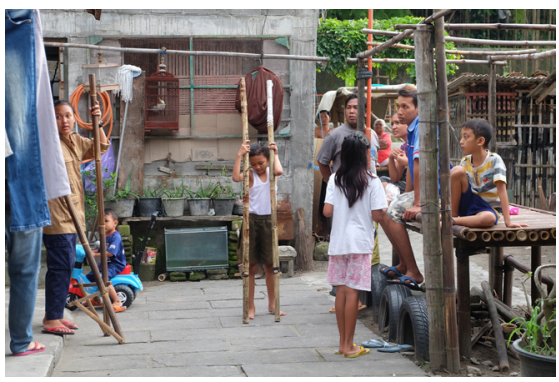

Figure 10. Public amenities: street lights. A quiet road atmosphere flight.

source: author's document, August 2017

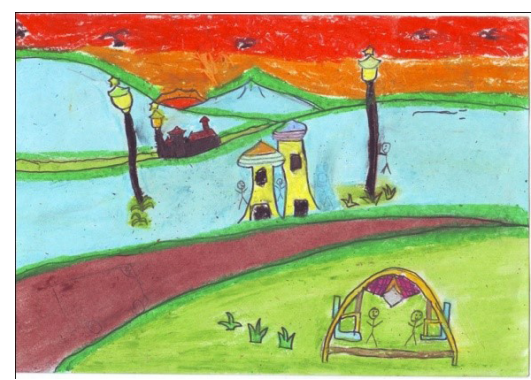

Whereas in the daily cycle, the afternoon time is the most comfortable playing time and for playing around the family. Figures 11 and 12 illustrate the opportunity for children to choose a conducive playing time element.

Figure11. Children and parents play relaxed in the afternoon, conducive weather conditions to gather play with friends / neighbors.

source: author's document, August 2017

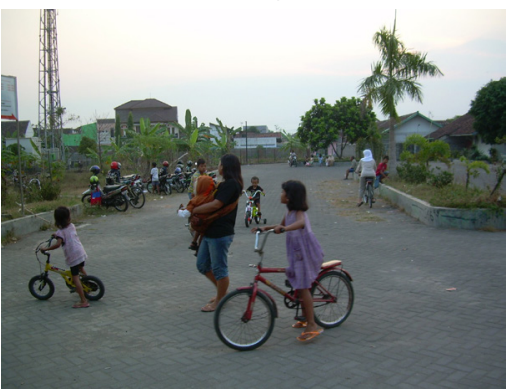

Figure12. Sunny time is a conducive opportunity for children to play around the house in Blimbingsari source: author's document, August 2017

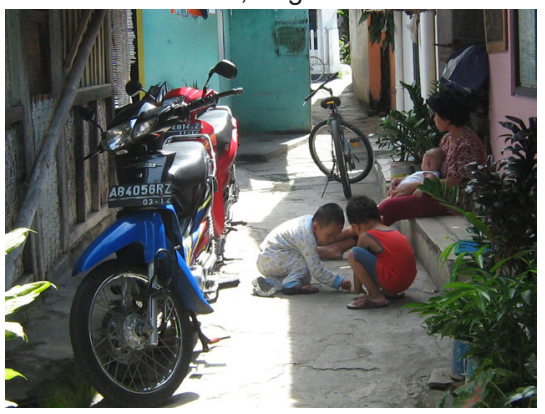


This game will be fun if the area is large enough so that children can run around and race the ball freely. The game is a social interaction experience between children. With this fun experience, children pour out their social experiences in pictures (Karczmarzyk, 2012). Hurlock (1995a) states that social interaction is very positive for child development. The hope of the child in this picture is that playing together with his friends can always be done.

\section{Conclusion}

Key point for this study is that in playing, children need residential public spaces which indicate the following conditions.

1. There are elements that can be used as "magnets" that invite children to play. Magnet in question can be in the form of physical environmental conditions, namely open land with relatively broad dimensions, public amenities, such as sitting benches, lighting, vegetation, etc.

2. Community becomes an important parameter for children's consideration to play.

3. Play tool is a tool that is always needed by children in play to build growth in cognition, affection, and psychomotor.

4. Ligthting is the main element in public amenities: sunlight at noon, and artificial lights at night. This lighting is needed for visual comfort when playing.

\section{Recomendation}

Structuring the housing environment needs to pay attention to facilities for children, namely a playroom that pleases children and can develop their cognition. Nature elements are equipped with trees, various plants, ponds that have fish and animals such as chickens, birds. Other el-ements that support motorics, for example swings, also need to be provided, which are also useful as a media for socialization.

\section{References}

Ancok, D. (2006). Outbond Manajement Training: Ilmu Perilaku dalam Pengembangan Sumber Daya Manusia, UII, Yogyakarta
Clark, A .(2005). Talking and Listening to Children, dalam Dudek, Mark, Children Spaces (hal 9), Architectural Press is an imprint of Elsevier, Oxford

Farokhi, M dan Hashemi, M. (2011). The Analisys of Children's Drawings: Social, Emotional, Psychological aspects, World Conference on Psychology, counselling and guidance. Retrieved from www. sciencedirect.com diakses 29 April 2017.

Gifford, R. (1987). Environmental Psychology, Principles and Practice, Allyn and bacon, Inc.

Halim, D. (2005). Psikologi Arsitektur, Pengantar Kajian Lintas Disiplin, Jakarta: Grasindo,

Haryadi dan Setiawan, B. (1995). Arsitektur Lingkungan dan Perilaku, Suatu Pengantar Ke Teori, Metodologi, dan Aplikasi, Proyek Pengembangan Pusat studi Lingkungan Dirjen Pendidikan Tinggi Departemen Pendidikan dan Kebudayaan Republik Indonesia, Gajah Mada University Press.

Hijriati .(2017). Peranan Dan Manfaat Ape Untuk Mendukung Kreativitas Anak Usia Dini, Jurnal Pendidikan, Volume III. Nomor 2. Juli - Desember 2017, hal 59- 69

Hurlock, E.B. (1995a). Perkembangan Anak, jilid 1, Jakarta: Erlangga.

Karczmarzyk, M.A. (2012). A Child in the Culture of Silence? The Meaning and Communi-cation in Children's Drawings, International Conference On New Horizons In Education Inte2012. Retrieved from www.sciencedirect.com diakses 29 April 2017

Latifah, U et al. (2015). Upaya Meningkatkan Interaksi Sosial Melalui Permainan Tradisional Jamuran Pada Anak Kelompok B TK Kuncup Sari Semarang Tahun Pelajaran 2014/2015, Jurnal Penelitian PAUDIA :112-132.

Loita, A. (2017). Karakteristik Pola Gambar Anak Usia Dini, Early Childhood: Jurnal Pendidikan, E-ISSN: 2579-7190/Vol.1 No.

1, 2017.

Marcus, C.C dan Francis, C. (1998). People Places, Design. New York: John Wiley and Sons Inc,

Mastuti, F et al. (2016). Model Ruang Publik pada Permukiman Padat Kota di Kawasan Pesisir, Prosiding Temu IImiah IPLBI 2016| C 065

Meiss, P.v (1990). Elements of Architecture, from Form to Place. New York: van Nostrand Reinhold 
Mimica, V. (1992). Notes on Children, Environment, and Architecture, Publikatieburo.

Oguz, V. (2010). The factors influencing childrens' drawings, WCES-2010. Retrieved from www.sciencedirect.com diakses 29 April 2017

Patilima, H. (2004). Persepsi Anak Mengenai Lingkungan Kota: Studi Kasus Ke-lurahan Kwitang, Jakarta Pusat. Tesis program pascasarjana Kajian Pengembangan Perkotaan Universitas Indonesia. Retrieved from www.xa.yimg.com/kq/ Persepsi+Anak+ Terhadap+Lingkungan+Kota. Diakses 30 November 2016.

Porteous, D. (1977). Environment and Behavior, planning and everyday urban life, Addison Wesley Publishing Company.

Robbin, S.P. (2003). Perilaku organisasi, Jakarta:Indeks

Said, I. (2007). Architecture For Children: Understanding Children Perception Towards Built Environment, proceeding International Conference: Challenges and Experiences in Developing Architectural Education in Asia, jurusan Arsitektur, FTSP, Universitas Islam Indonesia

Setiawan, B. (2006). Ruang Bermain untuk Anak di Kampung Kota: Studi Persepsi Lingkungan, Seting dan Perilaku Anak di Kampung Code Utara, Yogyakarta, Jurnal Manusia dan Lingkungan, vol 13, no 2, Juli 2006.

Vastu-shilpa Foundation. (1988). Residential Open Spaces a Behavioral Anaysis, Ahmedabad

White, R. dan Stoecklin, V. (1998). Children's Outdoor Play \& Learning Environments, (Maret/April 1998) issue of Early Childhood News magazine 